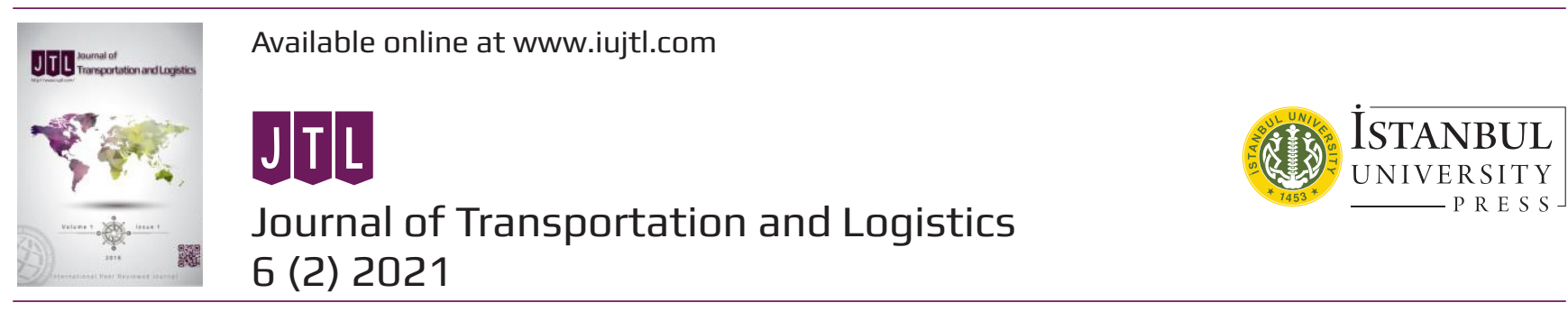

\title{
Mathematical Models for Milk Dispatching Problem
}

\author{
Süt Sevkiyat Problemi için Matematiksel Modeller
}

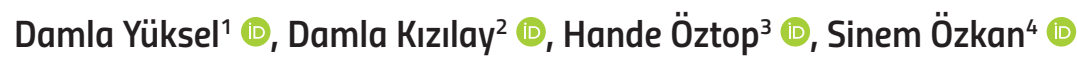

\section{ABSTRACT}

This study considers the milk dispatching problem for a small-sized distribution company. The milk dispatching problem can be seen in many reallife applications. Under a social responsibility project, several organizations, including companies and municipalities, distribute bottled milk for children to primary schools and impoverished families without any charge. These companies generally use capacitated vehicles for distribution and should consider available hours of the schools as well as the families. The planners generally want to minimize their expenses, such as fuel oil and storage costs. Under those restrictions, the problem turns out to be a capacitated vehicle routing problem with time windows (CVRPTW). One of the main objectives is to minimize total traveled distance considering the vehicle type to reduce the fuel consumption of the vehicles. Another objective is to minimize serving the customers late to reduce the storage cost of undelivered milk. To achieve those objectives, we formulated mixed-integer linear programming (MILP) and constraint programming (CP) models for the problem. To verify and compare our mathematical models, we modified well-known instances from the literature, including problem-specific parameters. The comprehensive computational results show that both models are very competitive for the problem. However, it should be noted that the MILP model outperforms the CP model in terms of solution quality and CPU time for the instances with a long planning horizon.

Keywords: Milk Dispatching Problem, Capacitated Vehicle Routing Problem with Time Windows, Mixed Integer Linear Programming Model, Constraint Programming Model

\section{öz}

Bu çalışma, küçük ölçekli bir dağıtım şirketi için şişelenmiş süt sevkiyat problemini ele almaktadır. Şişelenmiş süt sevkiyat problemi ile birçok gerçek hayat uygulamasında karşılaşabilmektedir. Sosyal sorumluluk projesi kapsamında, şirketler ve belediyeler dahil olmak üzere birçok organizasyon, çocuklar için ilkokullara ve yoksul ailelere ücretsiz olarak süt dağıtmaktadır. Bu şirketler genellikle belli bir kapasiteye sahip araçlar kullanarak ve müşterilerin (okullar ve aileler) uygun oldukları saat aralıklarını dikkate alarak dağıtım yapmaktadır. Planlama sürecinde genellikle akaryakıt ve depolama maliyetleri gibi masraflar en aza indirilmek istenmektedir. Bu kısıtlar altında, problemin, teslim zaman aralığı ve araç kapasitesi kısıtlı araç rotalama problemi (CVRPTW) olduğu ortaya çıkmaktadır. Temel hedeflerden biri, araçların yakıt tüketimini azaltmak için araç türünü dikkate alarak toplam seyahat mesafesini en aza indirmektir. Diğer bir amaç ise, zamanında teslim edilemeyen sütlerin depolama maliyetini azaltmak için, müşterilere uygun zaman aralıklarına göre hizmet vermek ve geç ürün teslimlerini azaltmaktır. Bu hedeflere ulaşmak amacıyla probleme özgü karmaşık tam sayılı doğrusal programlama (MILP) ve kısıt programlama (CP) modelleri geliştirilmiştir. Matematiksel modelleri doğrulamak ve karşılaştırmak için, literatürde oldukça bilinen veri setleri üzerinde probleme özgü parametreler dikkate alınarak bazı değişiklikler yapılmıştır. Detaylı analizlere ve sonuçlara göre, her iki modelin de çalışılan problem için oldukça rekabetçi olduğu gözlemlenmiştir. Ancak, uzun planlama vadesine sahip veri örnekleri için MILP modelinin CP modelinden çözüm kalitesi ve çözüm süresi açısından daha iyi performans gösterdiği görülmüştür. Anahtar Kelimeler: Süt Sevkiyat Problemi, Zaman Pencereli ve Kapasite Kısıtlı Araç Rotalama Problemi, Karmaşık Tamsayılı Doğrusal Programlama Modeli, Kısıt Programlama Modeli

Submitted: 21.05.2021 - Accepted: 04.08.2021

1 Damla Yüksel / Yasar University, Industrial Engineering Department, izmir, Turkey, E-mail: damla.yuksel@yasar.edu.tr, ORCID: 0000-0003-4630-3325

2 Corresponding author: Damla Kızılay / Izmir Democracy University, Industrial Engineering Department, İzmir, Turkey, E-mail: damla.kizilay@idu.edu.tr, ORCID: 0000-0002-6561-8819

3 Hande Öztop / Izmir Democracy University, Industrial Engineering Department, İmir, Turkey, E-mail: hande.oztop@idu.edu.tr, ORCID: 0000-0002-6503-7299

4 Sinem Özkan / Yasar University, Industrial Engineering Department, izmir, Turkey, E-mail: sinem.ozkan@yasar.edu.tr, ORCID: 0000-0002-7181-5800

Citation: Yuksel, D., Kizilay, D., Oztop, H., \& Ozkan, S. (2021). Mathematical models for milk dispatching problem. Journal of Transportation and Logistics, 6(2), 217-235. https://doi.org/10.26650/JTL.2021.940506 


\section{Introduction}

Social responsibility projects are carried out worldwide for years to help and support impoverished families, especially the kids and children. Based on this purpose, several organizations, such as charities, non-governmental organizations, and companies, implement a social responsibility project of milk dispatching. The aim is to provide needy families and kids the ability to access the healthy milk produced by the local cooperatives without any charge. Also, municipalities are included in these projects; for instance, İzmir Metropolitan Municipality of Turkey implements a milk distribution project with the collaboration of the producer cooperative. They dispatch bottled or boxed milk to primary schools in the city and impoverished families with children.

However, these kinds of projects are characterized by several challenges: high expenses of the distribution cost, time-consuming routes, availability of the nodes, and different vehicle capacities. Due to these factors, the companies investigate the possibility of turning these challenges into a competitive advantage while continuously improving their charity activities. One of the key activities to achieve this goal is efficient vehicle routing planning.

This study considers the milk dispatching problem for a small-sized company, motivated by the aforementioned real-life applications. In the studied problem, there are capacitated non-identical vehicles for distribution. Also, there are pre-determined available time windows of the customers (schools and families). Therefore, the problem is a capacitated vehicle routing problem with time windows (CVRPTW). The aim is to minimize total fuel cost based on traveled distance and the storage cost of undelivered milk based on the lateness of deliveries. In a dairy supply chain regarding the perishability of products, poor integration within a network may consist of high costs and excessive inventories with massive losses. Therefore, we consider exact models to provide effective solutions for the dairy distribution problem. Namely, we propose new mixed-integer linear programming (MILP) and constraint programming (CP) models for the problem.

In the perishable food sector, a dairy industry and milk collection-distribution problem becomes a challenging logistic problem and can benefit from the information technology (IT) and decision support systems (DSS) (Butler, Herlihy, \& Keenan, 2005). Several studies consider the milk collection problem, which includes the collection of raw milk from different farms (Caramia \& Guerriero, 2010) and applies a vehicle routing problem (VRP) (Claassen \& Hendriks, 2007) to lower the cost of milk transportation. ParedesBelmar, Marianov, Bronfman, Obreque, \& Lüer-Villagra, (2016) introduced a milk collection problem with blending. Collected milk from different farms has different qualities and is blended in the trucks. As the quality of the milk increases, also the revenue increases. The authors propose a MILP with a branch and cut algorithm. Also, a three-stage heuristic is proposed to solve the larger size instances. A similar collection and blending problem is studied by Paredes-Belmar, Lüer-Villagra, Marianov, Cortés, \& Bronfman, (2017). The authors propose an integer programming and branch and cut algorithm for the small size instances as well as the heuristic procedure based on the combination of the approximation and exact methods to solve the large size instances. 
The dairy transportation problem consists of determining the best routes for collecting milk from farms and delivering it to processing plants. Lahrichi, Crainic, Gendreau, Rei, \& Rousseau (2015) propose an approach based on scenario analysis that consists of revising both the steps and the information used to construct the routes through a generalized tabu search algorithm, which integrates the different characteristics of dairy transportation. In the study of Masson, Lahrichi, \& Rousseau (2016), the routes are determined using the historical data from the demands of the factories. It is stated that demand information leads to significant savings. They propose a two-stage method based on an adaptive large neighborhood search. The first phase solves the transportation problem, and the second phase ensures the optimization of plant assignment. Moreover, to optimize the profit of the dairy industries, a fuzzy linear programming model is proposed due to the uncertain supply of milk and demand of the dairy products (Fatih Demiral, 2013a). Also, the same authors propose a mixed-integer nonlinear programming model to solve the milk transportation problem (Fatih Demiral, 2013b). To address the fresh milk distribution, the problem is formulated as a heterogeneous fixed fleet vehicle routing problem and a threshold-accepting-based algorithm is proposed to solve the problem (Tarantilis \& Kiranoudis, 2001). Scheduling of raw milk collection and its transportation to the dairy factories are considered as VRP to minimize the costs (Sethanan \& Pitakaso, 2016). The authors propose a differential evolution heuristic and its variants to lower the traveling distance and trucks used in the system. Very recently, a different approach to solve the raw milk transportation problem is proposed by Paredes-Belmar, Montero, \& Leonardini (2021). They handled a real case in Chili where the farms are scattered in a large rural area. Therefore, the authors address the location of milk collection centers to reduce transportation costs. A mixed-integer linear programming model and a three-stage approach are proposed to solve the problem.

Besides the raw milk collection and dairy distribution problems, VRP is also applied to perishable food distribution, which has similar difficulties to the milk transportation problems. $\mathrm{ABC}$ customer classification and ant colony optimization are proposed to solve perishable food VRPTW (Gong \& Fu, 2010). Furthermore, a case study for a Portuguese food distribution company is addressed as heterogeneous fleet site-dependent VRP with multiple time windows (Amorim, Parragh, Sperandio, \& Almada-Lobo, 2014). An adaptive large neighborhood search heuristic is employed to generate the solution. In a soft drink distribution company, a vehicle routing problem with a heterogeneous vehicle fleet, time windows, capacity, and volume constraints is considered to minimize routing costs (Privé, Renaud, Boctor, \& Laporte, 2006).

In the literature, VRP has been investigated by several researchers over the years. The authors study several variants of the VRP, including time windows (Nalepa \& Blocho, 2016), capacitated vehicle (Sitek \& Wikarek, 2019), and multi-depot (Bae \& Moon, 2016) constraints. El-Sherbeny (2010) provided a detailed review of vehicle routing problems with time windows (VRPTW), including exact, heuristic, and meta-heuristic applications. For the VRP problems, besides providing the MILP model, other exact solution techniques such as developing and solving the CP model (De Backer, Furnon, Shaw, Kilby, \& Prosser, 2000; Hojabri, Gendreau, Potvin, \& Rousseau, 2018; Booth \& 
Beck, 2019; Hà et al., Hà et al., 2020; Öztop, Kizilay, \& Çil, 2020) as well as lagrangian relaxation (LR) (Guimarans, Herrero, Ramos, \& Padrón, 2011) are provided. Hojabri, Gendreau, Potvin, \& Rousseau (2018) and Hà et al. (2020) employ a CP approach for the VRP with synchronization constraints, whereas Booth \& Beck (2019) propose a CP model for the electric vehicle routing with time windows and Öztop, Kizilay, \& Çil (2020) develop a CP model for a periodic VRP with time windows and time spread constraints.

However, most of the studies in the literature use MILP models for the VRP, only a few studies have employed the CP to solve the VRP. Furthermore, these exact solution techniques are generally used in a metaheuristic framework since the VRP is an NPhard problem (Johnson \& Garey, 1979). Detailed analysis of VRPTW, CVRP, and the other variants is provided in the overview of Kumar \& Panneerselvam (2012). Also, the most recent survey, including all the characteristics of the VRP and a wide range of classifications on solution methodologies, are presented by Braekers, Ramaekers, \& Van Nieuwenhuyse (2016).

In recent years, CVRPTW problems have been applied in different areas. For example, Li et al. (2020) develop an improved artificial bee colony algorithm for the dispatching problem of the prefabricated components to construction sites in a prefabricated system. Another real-life case study can be seen in the study by Tebaldi, Murino, \& Bottani (2020), where they carry out a water wave optimization algorithm for the CVRPTW. As a very recent study, Sitek et al. (2021) consider the hybridization of CP, genetic algorithm and mathematical programming for solving CVRPs with alternative delivery, pick-up and time windows. Hence, CVRPs are still on the focus of all researchers over different industries/areas.

The following classification in Table 1 is provided for researchers to find relevant literature quickly.

Table 1 summarizes the literature by presenting the studied problem, objective function, solution methodology, and the problem-specific classification: perishable goods and milk transportation. Only 12 articles have dealt with the problems encountered in the dairy industry. Therefore, less work has been performed on milk dispatching/distribution problems in the literature. As seen from the literature, most of the studies related to perishable goods and milk distribution handle the VRP and its several variants. The majority of the studies apply heuristic or metaheuristic solution techniques due to the NP-hardness nature of the VRP. Only a few studies include the CP model for the VRP variants, and three of them embed the CP in heuristic algorithms. Different from the presented CP models in the literature, this study provides a scheduling-based $\mathrm{CP}$ model for the CVRPTW to minimize the fuel consumption of the vehicles and storage cost of undelivered milk based on the lateness of deliveries, as well as a MILP model. The performance of the $\mathrm{CP}$ model on the scheduling problems has become a strong competitor to standard mathematical modeling methods such as MILP (Rossi, Van Beek, \& Walsh, 2006). 
Table 1. Classification of the Literature Review

\begin{tabular}{|c|c|c|c|c|c|}
\hline Author(s)/Year & Problem & Objective & Solution Methodologies & $\begin{array}{l}\text { Perishable } \\
\text { Food }\end{array}$ & $\begin{array}{c}\text { Milk } \\
\text { Industry }\end{array}$ \\
\hline Solomon (1987) & VRPTW & $\begin{array}{l}\text { Minimum-cost vehicle } \\
\text { routes }\end{array}$ & Insertion-type heuristic & & \\
\hline $\begin{array}{l}\text { De Backer et al. } \\
(2000)\end{array}$ & VRP & $\begin{array}{l}\text { Minimize costs related to } \\
\text { the number of vehicles } \\
\text { and to distance traveled }\end{array}$ & $\begin{array}{l}\text { Local search techniques with } \mathrm{CP} \text {, } \\
\text { tabu search, constraint guided } \\
\text { search }\end{array}$ & & \\
\hline $\begin{array}{l}\text { Tarantilis \& } \\
\text { Kiranoudis (2001) }\end{array}$ & $\begin{array}{l}\text { Fresh milk } \\
\text { distribution, } \\
\text { heterogeneous fixed } \\
\text { fleet VRP }\end{array}$ & $\begin{array}{l}\text { Total transportation cost } \\
\text { minimization }\end{array}$ & $\begin{array}{l}\text { Backtracking adaptive threshold } \\
\text { accepting algorithm }\end{array}$ & & $\mathrm{X}$ \\
\hline Butler et al. (2005) & $\begin{array}{l}\text { Milk collection } \\
\text { problem }\end{array}$ & & IT and DSS & & $\mathrm{X}$ \\
\hline Privé et al. (2006) & $\begin{array}{l}\text { The VRP with a } \\
\text { heterogeneous } \\
\text { vehicle fleet, time } \\
\text { windows, capacity, } \\
\text { and volume } \\
\text { constraints }\end{array}$ & $\begin{array}{l}\text { Total cost (routing costs - } \\
\text { the revenue from the sale } \\
\text { of recyclable material) } \\
\text { minimization }\end{array}$ & $\begin{array}{l}\text { MILP model, three construction } \\
\text { heuristics, an improvement } \\
\text { procedure }\end{array}$ & $\mathrm{X}$ & \\
\hline $\begin{array}{l}\text { Claassen \& } \\
\text { Hendriks (2007) }\end{array}$ & Periodic VRP & $\begin{array}{l}\text { Minimize the total } \\
\text { weighted sum of } \\
\text { deviations on the demand } \\
\text { level }\end{array}$ & $\begin{array}{l}\text { Branch and bound, special } \\
\text { ordered sets, DSS }\end{array}$ & & $\mathrm{X}$ \\
\hline $\begin{array}{l}\text { Caramia \& } \\
\text { Guerriero (2010) }\end{array}$ & $\begin{array}{l}\text { Milk collection } \\
\text { problem }\end{array}$ & $\begin{array}{l}\text { Minimization of tour } \\
\text { length }\end{array}$ & Multiple start mechanism & & $\mathrm{X}$ \\
\hline El-Sherbeny (2010) & $\begin{array}{l}\text { CVRPTW with } \\
\text { identical vehicles }\end{array}$ & $\begin{array}{l}\text { Distance-based total cost } \\
\text { minimization }\end{array}$ & MILP model & & \\
\hline Gong \& Fu (2010) & CVRPTW & $\begin{array}{l}\text { Fixed vehicle cost, } \\
\text { operation cost, shelf life } \\
\text { loss, and default cost } \\
\text { minimization }\end{array}$ & $\begin{array}{l}\text { Multi-objective mathematical } \\
\text { model, ant colony optimization } \\
\text { with } \mathrm{ABC} \text { customer classification } \\
\text { algorithm }\end{array}$ & $\mathrm{X}$ & \\
\hline $\begin{array}{l}\text { Guimarans et al. } \\
\text { (2011) }\end{array}$ & CVRP & $\begin{array}{l}\text { Minimizing total travel } \\
\text { cost }\end{array}$ & $\mathrm{CP}$ and LR based metaheuristics & & \\
\hline $\begin{array}{l}\text { Fatih Demiral } \\
(2013 a)\end{array}$ & Production planning & Maximum profit & $\begin{array}{l}\text { A fuzzy linear programming } \\
\text { model }\end{array}$ & & $\mathrm{X}$ \\
\hline $\begin{array}{l}\text { Fatih Demiral } \\
(2013 b)\end{array}$ & Production planning & Maximum profit & MIP & & $\mathrm{X}$ \\
\hline $\begin{array}{l}\text { Amorim et al. } \\
(2014)\end{array}$ & $\begin{array}{l}\text { The heterogeneous } \\
\text { fleet site-dependent } \\
\text { VRP with multiple } \\
\text { hard time windows }\end{array}$ & $\begin{array}{l}\text { Travel cost }+ \text { renting } \\
\text { vehicle cost }+ \text { driver cost } \\
\text { minimization }\end{array}$ & $\begin{array}{l}\text { MILP model, the adaptive large } \\
\text { neighborhood search algorithm }\end{array}$ & $\mathrm{X}$ & \\
\hline $\begin{array}{l}\text { Lahrichi et al. } \\
(2015)\end{array}$ & $\begin{array}{l}\text { Dairy transportation } \\
\text { problem }\end{array}$ & $\begin{array}{l}\text { Transportation cost } \\
\text { minimization }\end{array}$ & $\begin{array}{l}\text { A generalized tabu search } \\
\text { algorithm }\end{array}$ & & $X$ \\
\hline $\begin{array}{l}\text { Bae \& Moon } \\
(2016)\end{array}$ & Multi-depot VRPTW & $\begin{array}{l}\text { Minimize total costs } \\
\text { of depots, vehicles, } \\
\text { transportation, and labor }\end{array}$ & $\begin{array}{l}\text { A heuristic algorithm, a hybrid } \\
\text { genetic algorithm }\end{array}$ & & \\
\hline $\begin{array}{l}\text { Masson et al. } \\
(2016)\end{array}$ & $\begin{array}{l}\text { The annual dairy } \\
\text { transportation } \\
\text { problem } \\
\text { (heterogeneous } \\
\text { fleet of capacitated } \\
\text { vehicles, multiple } \\
\text { depots) }\end{array}$ & $\begin{array}{l}\text { Distance-based total cost } \\
\text { minimization }\end{array}$ & $\begin{array}{l}\text { MIP model, a two-stage adaptive } \\
\text { large neighborhood search } \\
\text { algorithm }\end{array}$ & & $\mathrm{X}$ \\
\hline $\begin{array}{l}\text { Nalepa \& Blocho } \\
(2016)\end{array}$ & $\begin{array}{l}\text { CVRPTW with } \\
\text { identical vehicles }\end{array}$ & $\begin{array}{l}\text { Distance-based total cost } \\
+ \text { fleet size minimization }\end{array}$ & $\begin{array}{l}\text { MIP model, adaptive memetic } \\
\text { algorithm }\end{array}$ & & \\
\hline
\end{tabular}


Table 1. Continue

\begin{tabular}{|c|c|c|c|c|c|}
\hline Author(s)/Year & Problem & Objective & Solution Methodologies & $\begin{array}{l}\text { Perishable } \\
\text { Food }\end{array}$ & $\begin{array}{c}\text { Milk } \\
\text { Industry }\end{array}$ \\
\hline $\begin{array}{l}\text { Sethanan \& } \\
\text { Pitakaso (2016) }\end{array}$ & $\begin{array}{l}\text { Raw milk collection } \\
\text { from collection } \\
\text { centers to dairy } \\
\text { factories }\end{array}$ & $\begin{array}{l}\text { Minimizing the total } \\
\text { costs, considering } \\
\text { fuel costs and costs of } \\
\text { cleaning and sanitizing } \\
\text { raw milk tanks on } \\
\text { vehicles }\end{array}$ & Differential evolution algorithm & & $\mathrm{X}$ \\
\hline $\begin{array}{l}\text { Paredes-Belmar et } \\
\text { al. (2016) }\end{array}$ & $\begin{array}{l}\text { Milk collection } \\
\text { problem with } \\
\text { blending }\end{array}$ & Maximum profit & $\begin{array}{l}\text { A branch-and-cut algorithm, } \\
\text { three-stage heuristics }\end{array}$ & & $\mathrm{X}$ \\
\hline $\begin{array}{l}\text { Paredes-Belmar et } \\
\text { al. (2017) }\end{array}$ & $\begin{array}{l}\text { Milk collection } \\
\text { problem with } \\
\text { blending }\end{array}$ & Maximum profit & $\begin{array}{l}\text { Branch-and-cut algorithm, } \\
\text { heuristics }\end{array}$ & & $\mathrm{X}$ \\
\hline $\begin{array}{l}\text { Hojabri et al. } \\
\text { (2018) }\end{array}$ & $\begin{array}{l}\text { VRP with } \\
\text { synchronization } \\
\text { constraints }\end{array}$ & $\begin{array}{l}\text { Minimize the total } \\
\text { distance traveled by the } \\
\text { vehicles }\end{array}$ & $\begin{array}{l}\text { A constraint programming-based } \\
\text { adaptive large neighborhood } \\
\text { search }\end{array}$ & & \\
\hline $\begin{array}{l}\text { Booth \& Beck } \\
(2019)\end{array}$ & $\begin{array}{l}\text { Electric VRP with } \\
\text { time windows }\end{array}$ & $\begin{array}{l}\text { Various objectives } \\
\text { including distance } \\
\text { minimization }\end{array}$ & $\begin{array}{l}\text { CP models, hybrid MILP-CP } \\
\text { approach }\end{array}$ & & \\
\hline $\begin{array}{l}\text { Sitek \& Wikarek } \\
\text { (2019) }\end{array}$ & $\begin{array}{l}\text { Capacitated vehicle } \\
\text { routing problem } \\
\text { with pick-up and } \\
\text { alternative delivery }\end{array}$ & $\begin{array}{l}\text { Minimum traveling } \\
\text { distance }\end{array}$ & $\begin{array}{l}\text { Constraint logic programming, } \\
\text { metaheuristics }\end{array}$ & & \\
\hline Hà et al. (2020) & $\begin{array}{l}\text { VRP with } \\
\text { synchronization } \\
\text { constraints }\end{array}$ & Minimize total travel cost & $\begin{array}{l}\text { CP model, adaptive large } \\
\text { neighborhood search }\end{array}$ & & \\
\hline Li et al. (2020) & CVRPTW & $\begin{array}{l}\text { Minimize the sum of the } \\
\text { energy consumptions of } \\
\text { the vehicles }\end{array}$ & $\begin{array}{l}\text { Improved artificial bee colony } \\
\text { (IABC) algorithm }\end{array}$ & & \\
\hline $\begin{array}{l}\text { Tebaldi et al. } \\
(2020)\end{array}$ & CVRPTW & $\begin{array}{l}\text { Minimize the travel } \\
\text { distance and time }\end{array}$ & Water wave optimization & & \\
\hline $\begin{array}{l}\text { Paredes-Belmar et } \\
\text { al. }(2021)\end{array}$ & VRP & $\begin{array}{l}\text { Minimum transportation } \\
\text { cost }\end{array}$ & MILP, iterated local search & & $\mathrm{X}$ \\
\hline Öztop et al. (2020) & $\begin{array}{l}\text { Periodic VRP with } \\
\text { time windows } \\
\text { and time spread } \\
\text { constraints }\end{array}$ & $\begin{array}{l}\text { Minimize total travel } \\
\text { time of the vehicles }\end{array}$ & MILP model, CP model & & \\
\hline Sitek et al. (2021) & $\begin{array}{l}\text { CVRP with } \\
\text { alternative delivery, } \\
\text { pick-up and time } \\
\text { windows }\end{array}$ & Minimize the route length & $\begin{array}{l}\text { BIP, a hybrid approach } \\
\text { combining CP, GA and } \\
\text { mathematical programming }\end{array}$ & & \\
\hline
\end{tabular}

The research objective of this study is the minimization of resource usage of dispatching organizations that want to help through social responsibility projects while distributing milk to primary schools and impoverished families with children. These activities are the processes those dispatching organizations, such as non-governmental organizations, local municipalities and/or all organizations that want to help, carry out with the support of their employees daily, weekly, or monthly. Since no revenue is aimed to be obtained by these processes, the only purpose is to optimize resource usage, which is the total fuel consumption of vehicles and the total lateness cost of the delayed milk deliveries. 
The rest of the paper is organized as follows: Section 2 gives the detailed problem definition and the parameters used by the mathematical models. Section 3 presents the proposed MILP model, while Section 4 includes the developed CP formulation for the CVRPTW. Section 5 presents the results of the computational experiments for all presented models, including data generation and the comparison of the models. Finally, Section 6 addresses some concluding remarks and some directions for future works.

\section{Problem Definition}

As mentioned in Section 1, there are milk distribution projects carried out within the scope of social responsibility projects in many countries of the world. This study was inspired by these milk distribution projects, which dispatch bottled or boxed milk to primary schools and impoverished families with children.

In this study, the distribution company is assumed to have a single depot. It distributes the milk from the depot and returns undelivered milk to the depot again. In order to distribute the milk, the company uses three types of vehicles, i.e., trucks, sprinter vans, and minivans, with different capacities. Every day, vehicles depart from the depot of the company and distribute the milk throughout the city. The demand for each day is known at the beginning of the day, and distribution continues for 8 hours between 9:00 am and 5:00 pm. Each school and family have different available time intervals, and the distributors should respect those intervals when delivering the milk. Therefore, we consider the problem as a capacitated vehicle routing problem with time windows.

The companies that maintain these social responsibility projects are planning to achieve their goals by minimizing the expenses related to the project. Furthermore, they generally want to spend less route time on the distribution of milk. As mentioned above, there are different types of vehicles. Hence, each type of vehicle consumes a different amount of fuel oil with respect to its size. Also, traveled distance affects the fuel oil consumption of the vehicles. Therefore, developed models aim to minimize the total traveled distance of each vehicle concerning their fuel oil consumption costs.

As mentioned before, if distributors cannot deliver demanded milk to the customers due to the violation of the time windows, then undelivered milk will be returned to the depot. Therefore, the company pays an additional storage cost for the undelivered milk. For this reason, another objective is to minimize the storage costs for the undelivered milk of the late deliveries.

If a vehicle arrives at the customer just before its upper limit of the time windows, but the service time exceeds the upper limit, then some of the milk may not be delivered to that customer. Hence, it is not enough to arrive at the customers before their availability ends; arrival time and the service time should be within the time window limits to deliver all demanded milk. Some customers are more flexible and can wait until service finishes even if the service time exceeds their time windows. However, some of the customers, especially schools, are strict with their time windows. If the service exceeds the school closing time, then some of the demands will not be delivered to the schools, and that milk will be returned to the depot. The storage cost of undelivered milk is calculated by 
considering the acceptance rate of the schools and the families for late delivery of milk. Namely, the unit storage cost is multiplied by the demand and the rejection rate of each customer. The storage cost of undelivered milk for each customer $i$ is considered as a penalty $\operatorname{cost} p_{i}$ for that customer for a late visit.

Both the mixed-integer linear programming model and the constraint programming model are developed to solve the milk dispatching problem. The following sections provide a detailed explanation of the formulations. Sets and parameters used in both models are defined below:

\section{Sets and Parameters:}

$N=\{0, \ldots, D\} \quad$ Set of nodes including depots, where vertex 0 is the driving-out depot and $D$ is the returning depot.

$C=\{1, \ldots, D-1\} \quad$ Set of customers.

$V=\{1, \ldots, K\} \quad$ Set of vehicles.

M: $\quad$ Sufficiently large constant integer.

$q_{k}: \quad$ Capacity of vehicle $k \in V$.

$f_{k}$ : Cost of fuel consumption per unit distance for vehicle $k \in V$.

$d_{i}: \quad$ Demand at node $i \in N$.

$t_{i, j}: \quad$ Travel time/distance from node $i \in N$ to node $j \in N$

$a_{i}$ : $\quad$ Starting time of a time window for node $i \in N$

$b_{i}$ : $\quad$ Ending time of a time window for node $i \in N$

$s_{i}: \quad$ Service time of node $i \in N$.

$p_{i}$ : $\quad$ Penalty cost per unit time for visiting node $i \in N$ out of the given time window, which is based on the storage cost of undelivered milk.

\section{Mixed Integer Linear Programming Model}

The decision variables, the objective function, and the constraints of the proposed MILP model are explained as follows:

\section{Decision Variables:}

$y_{k, i, j}: \quad 1$ if the vehicle $k \in V$ visits node $i \in N$ immediately before node $j \in N$; 0 otherwise.

start $_{i}$ : Start time of service at customer $i \in C$.

late $_{i}$ : $\quad$ Amount of time that customer $i \in C$ is served late.

\section{Objective Function}

Minimize $\sum_{i, j \in N \mid i \neq j, k \in V} t_{i, j} y_{k, i, j} f_{k}+\sum_{i \in C} p_{i}$ late $_{i}$ 


\section{Constraints}

$\begin{array}{ll}\sum_{k \in V, j \in N \mid i \neq j} y_{k, i, j}=1 & \forall i \in C \\ \sum_{i \in N} d_{i} \sum_{j \in N \mid i \neq j} y_{k, i, j} \leq q_{k} & \forall k \in V \\ \sum_{j \in N \mid j \neq 0} y_{k, 0, j}=1 & \forall k \in V \\ \sum_{i \in N \mid i \neq h} y_{k, i, h}-\sum_{j \in N \mid h \neq j} y_{k, h, j}=0 & \forall h \in C, k \in V \\ \sum_{i \in N \mid i \neq D} y_{k, i, D}=1 & \forall k \in V \\ \text { start }_{i} \geq a_{i} & \forall i \in N \\ \text { late }_{i} \geq \text { start }_{i}+s_{i}-b_{i} & \forall i \in N \\ \text { start }_{j}-\text { start }_{i}-t_{i, j}-s_{i}+M\left(1-y_{k, i, j}\right) \geq 0 & \forall i, j \in N \mid i \neq j, k \in V \\ \operatorname{yk}_{k, i, j} \in\{0,1\} & \forall i, j \in N, k \in V \\ \text { start }_{i}, \text { late }_{i} \geq 0 & \forall i \in N\end{array}$

The aim is to minimize the total costs incurred by the fuel consumption and the lateness cost. Therefore, the objective function has two parts. The first part minimizes the fuel consumption of each vehicle by minimizing the total traveled distance. The second part minimizes the cost of late delivery based on the storage cost of undelivered milk. If any customer is visited later than its available periods, then the milk may not be delivered to those customers. Undelivered milk is returned to the depots and stored.

Constraint (3.1) ensures that each customer is visited exactly once, while constraint (3.2) provides that each vehicle can be loaded up to its capacity limit. The constraint sets ( 3.3 - 3.5) state that each vehicle starts its tour from the depot (0), visits the customers by entering and leaving each node on its tour, and finishes its tour at the depot (D) again. The customers cannot be visited before their lower limit of the time windows. Constraint (3.6) provides that the service start time for each customer should be greater than or equal to $a_{i}$. Constraint (3.7) calculates the late arrivals to the customers considering the service time. Constraint (3.8) ensures that if a vehicle travels from customer $i$ to $j$ immediately, then it should arrive at customer $j$ after visiting and serving customer $i$ regarding the travel time in between. The remaining constraints (3.9 and 3.10) define the domain of the decision variables.

\section{Constraint Programming Model}

The following model presents the decision variables, the objective function, and the constraints of the CP model using the OPL modeling language (Hentenryck, 1999). The $\mathrm{CP}$ is distinguished from the relaxation techniques and polyhedral analysis by its inference and modeling power (Hentenryck, 2002). To express the handling time of the vehicles, the model uses optional interval variables. Also, for each vehicle, sequence variables are declared in the model. Each sequence constraint collects all optional interval variables associated with a specific vehicle. 


\section{Decision Variables:}

$n d_{i}$ : $\quad$ Interval variable for visiting node $i \in N$ between $a_{i}$ and $M$.

$y_{i, k}: \quad$ Optional interval variable for serving node $i \in N$ by vehicle $k \in V$ with duration $s_{i}$.

$v h_{k}$ : Sequence variable for vehicle $k \in V$ over $\left\{y_{i, k} \mid i \in N\right\}$.

\section{Objective Function}

Minimize $\sum_{i \in N} \sum_{k \in V} t_{i, \operatorname{TYPOFNEXT}\left(v h_{k}, y_{i, k}, i, i\right.} f_{k}+\sum_{i \in C} \sum_{k \in V} p_{i} \boldsymbol{m a x}\left(\operatorname{ENDOF}\left(\boldsymbol{y}_{i, \boldsymbol{k}}\right)-\boldsymbol{b}_{\boldsymbol{i}}, \mathbf{0}\right)$

\section{Constraints}

\begin{tabular}{|c|c|}
\hline $\operatorname{ALTERNATIVE}\left(n d_{i}, \operatorname{all}(k\right.$ in $\left.V) y_{i, k}\right)$ & $\forall i \in C$ \\
\hline $\operatorname{ALTERNATIVE}\left(n d_{i}, \operatorname{all}(k\right.$ in $\left.V) y_{i, k},|V|\right)$ & $\forall i \in N \mid i=0, i=D$ \\
\hline$\sum_{i \in N} d_{i} * \operatorname{PRESENCEOF}\left(y_{i, k}\right) \leq q_{k}$ & $\forall k \in V$ \\
\hline $\operatorname{FIRST}\left(v h_{k}, y_{0, k}\right)$ & $\forall k \in V$ \\
\hline $\operatorname{LAST}\left(v h_{k}, y_{D, k}\right)$ & $\forall k \in V$ \\
\hline $\operatorname{NOOVERLAP}\left(v h_{k}, t_{i, j}\right)$ & $\forall k \in V$ \\
\hline
\end{tabular}

The CP model has the same objective as the MILP model. The first part minimizes the fuel consumption of each vehicle by minimizing the total traveled distance. In this part, TYPEOFNEXT function is used as the index of the customer who is visited after customer $i$. The second part minimizes the cost of late delivery by calculating the amount of time that the customers are served late. In this part, ENDOF function is used to compute the completion time of the service for each customer.

The lower limit of the time windows is respected while defining the interval variable $n d_{i}$. The other constraints are explained as follows. Alternative constraints (4.1 and 4.2) ensure that exactly one vehicle visits a customer, and each vehicle visits both depots (0 and D). Constraint (4.3) states that vehicles cannot be loaded more than their capacities. Constraint sets (4.4 and 4.5) provide that the first and the last node should be the depot in the traveling sequence of each vehicle. Vehicles can visit only a single node at a time, which is represented by NOOverLAP constraint (4.6) over the sequence variables associated with the vehicles. This constraint also enforces the transition time between successive nodes, forcing the travel time between each node.

\section{Computational Experiment}

The MILP and CP models aim to solve the same problem by looking from different points of view at the problem studied. The MILP model carries out a binary variable to decide which vehicle will be visiting which node in which order. Also, the starting time of service for customers as well as the amount of time the customers have been served late are implemented on the model with continuous decision variables. On the other hand, the CP model carries out an interval variable as well as an optional interval variable 
and a sequence variable to reach the same decisions. Moreover, the CP model employs special CP functions, such as "NOOVERLAP", "FIRST", "LAST", "PRESENCEOF", and "ALTERNATIVE". Thus, the CP model is based on a scheduling point of view. In order to evaluate the performance of the proposed models, we perform a comprehensive computational experiment by generating 560 test instances. Initially, we explain the data generation procedure in Section 5.1. Then, we present the detailed computational results for the models in Section 5.2.

\subsection{Data Generation}

The test instances are generated by modifying the well-known benchmark instances of Solomon (1987). Those 56 instances of Solomon were originally created for the CVRPTW, where there are six subsets (R1, R2, C1, C2, RC1, RC2). These 56 instances include the following data: the number of customers, the vehicle capacity, Euclidean coordinates of the nodes, demand, service time, and the time windows of the nodes. Subsets R1 (12 instances) and R2 (11 instances) contain only randomly dispersed nodes, subsets C1 (9 instances) and $\mathrm{C} 2$ (8 instances) contain only clustered customers, whereas subsets RC1 (8 instances) and RC2 (8 instances) contain both randomly dispersed and clustered nodes. Instance subsets of type 1 have a short planning horizon, while the instance subsets of type 2 have a long planning horizon. Within a subset, the instances differ according to the width of the time windows. All the instances have 100 customers and 25 identical vehicles.

As mentioned above, it was assumed that all the vehicles are identical in the instances of Solomon, i.e., they have the same capacities. However, in our study, it is assumed that different types of vehicles have various capacities. Moreover, the benchmark sets of Solomon do not have fuel oil and storage costs. Therefore, we modified the instances of Solomon by including different vehicle types, fuel oil costs, and storage costs.

It is assumed that there are three types of vehicles in our study: trucks, sprinter vans, and minivans. The truck has the largest capacity and can carry up to 400 bottles of milk. The sprinter van has less capacity than the truck and can transport up to 200 bottles. Minivans are the smallest vehicles that have the capacity of 100 bottles of milk. The amount of fuel consumed by the vehicles varies according to their size, so the cost of fuel oil is different for each type of vehicle. The fuel oil cost per unit distance is calculated for each vehicle type. While the fuel cost is 0.75 per unit distance for the trucks, it is 0.60 for the sprinter vans, and 0.45 for the minivans.

Additionally, the storage cost of milk is calculated by considering the acceptance rate of the schools and the families for late delivery of milk. It is assumed that the acceptance rate of late delivery is $90 \%$ for families and $60 \%$ for schools. The unit storage cost is multiplied by the demand and the rejection rate of each customer $(0.40$ for schools, 0.10 for families). Namely, the storage costs of the milk are calculated by multiplying the unit storage cost by the undelivered amounts. Those undelivered amounts are obtained by multiplying the demands of the schools with 0.40 and families with 0.10 . All the necessary calculations are done while generating the parameter $p_{i}$. 
As mentioned above, the instances of Solomon have 100 customers and 25 vehicles. However, in our study, we want to test and see the performance of our mathematical models on small-sized instance sets, as we propose exact solution methodologies. Therefore, we cropped those 56 instances to have instances with ten customers. Thus, every single benchmark instance with 100 customers of Solomon provides ten different instances with ten customers for our study. Since there is a total of 56 instances with 100 customers, we have a total of 560 instances with ten customers. Note that, in each of these 560 instances, we assumed that there are three non-identical vehicles.

\subsection{Computational Results}

As mentioned in Section 5.1, the computational experiment has been conducted on 560 instances with ten customers and three vehicles. There are six subsets (R1, R2, C1, C2, $\mathrm{RC} 1, \mathrm{RC} 2$ ) for these instances. There are 120 instances for subset R1, 110 instances for subset R2, 90 instances for subset $\mathrm{C} 1,80$ instances for subset $\mathrm{C} 2,80$ instances for subset $\mathrm{RC} 1$, and 80 instances for subset RC2.

In the computational experiment, both MILP and CP models are coded in the IBM ILOG CPLEX Optimization Studio platform and solved with CPLEX 12.8. CP Optimizer suite of IBM ILOG CPLEX 12.8 is used to solve the CP model. For both models, the default setting of the OPL is used. The model results are obtained for all instances with a 1-hour time limit on an Intel Core i7-5500U CPU $2.40 \mathrm{GHz}$ computer.

The relative percentage deviation (RPD) is used as a performance measure for the comparison of the models. The RPD is calculated for each instance as follows:

$R P D=100 *\left(C_{M}-C_{B e s t}\right) / C_{B e s t}$

where $C_{M}$ is the objective function value found by any model (MILP or CP), and $C_{B E S T}$ is the best objective function value that is obtained among the both models.

The average RPD (ARPD) of the MILP and CP models are reported for each instance set (R1, R2, C1, C2, RC1, RC2) in Tables 2-7, as well as the number of optimal solutions found and the average CPU time. The first column of the table represents each subset of instances grouped according to the original instance name (Solomon, 1987). Next, the average RPD values and the average CPU time (in seconds) are computed for the generated instances from the same original instance of Solomon, (1987). As mentioned in Section 5.1, we generate ten instances from each original instance of Solomon. Therefore, these average RPD and CPU results of each subset are the average values over ten instances. For example, instance subset "R101 1-10" represents the ten instances generated from the original "R101" instance of Solomon. Then, for a given model, "ARPD", "\# of Opt." and "Avg. CPU" columns of the table present the ARPD value, the number of optimal solutions found, and the average CPU value for each subset of instances. Finally, for a given model, the final row of the table presents the average ARPD value, the total number of optimal solutions found and the average CPU value overall for an instance set. 
As shown in Table 2, the MILP model obtains the optimal result for all instances of the set R1. Therefore, its RPD values are zero for all the instances. Also, the average CPU time of the MILP is 15.30 seconds overall. On the other hand, the CP model finds the optimal result for 117 out of 120 instances of the set R1, and its average ARPD value is $0.13 \%$ overall. Also, the average CPU time of the CP is 184.47 seconds overall. Thus, even though both models perform well for these instances, it can be said that the proposed MILP model slightly outperforms the CP model in terms of both CPU time and the number of optimal solutions found.

As seen in Table 3, the MILP model finds the optimal result for all instances of the set R2, and its RPD values are zero for all the instances. The average CPU time of the MILP is 9.82 seconds overall. On the other hand, the CP model finds the optimal result for only 34 out of 110 instances of the set R2, and its average ARPD value is $7.91 \%$ overall. Also, the overall average CPU time of the CP is 2727.17 seconds, which is much higher than those of the MILP model. Consequently, it can be said that the MILP model clearly outperforms the CP model for these instances in terms of all performance criteria.

Table 2. The results of the MILP and CP models for the instance set R1

\begin{tabular}{|l|c|c|c|c|c|c|}
\hline \multirow{2}{*}{$\begin{array}{l}\text { Instance } \\
\text { Subset }\end{array}$} & \multicolumn{3}{|c|}{ MILP } & \multicolumn{3}{c|}{ CP } \\
\cline { 2 - 7 } & ARPD & \# of Opt. & Avg. CPU & ARPD & \# of Opt. & Avg. CPU \\
\hline R101 1-10 & 0.00 & 10 & 6.94 & 0.00 & 10 & 5.64 \\
\hline R102 1-10 & 0.00 & 10 & 18.03 & 0.00 & 10 & 17.38 \\
\hline R103 1-10 & 0.00 & 10 & 11.86 & 0.00 & 10 & 71.01 \\
\hline R104 1-10 & 0.00 & 10 & 16.27 & 0.00 & 10 & 239.98 \\
\hline R105 1-10 & 0.00 & 10 & 5.91 & 0.00 & 10 & 7.64 \\
\hline R106 1-10 & 0.00 & 10 & 12.10 & 0.00 & 10 & 25.12 \\
\hline R107 1-10 & 0.00 & 10 & 15.01 & 0.00 & 10 & 130.16 \\
\hline R108 1-10 & 0.00 & 10 & 26.28 & 0.00 & 9 & 654.93 \\
\hline R109 1-10 & 0.00 & 10 & 6.56 & 0.00 & 10 & 20.20 \\
\hline R110 1-10 & 0.00 & 10 & 14.01 & 0.00 & 10 & 52.23 \\
\hline R111 1-10 & 0.00 & 10 & 16.41 & 0.00 & 10 & 109.46 \\
\hline R112 1-10 & 0.00 & 10 & 34.24 & 1.59 & 8 & 879.94 \\
\hline Overall & $\mathbf{0 . 0 0}$ & $\mathbf{1 2 0}$ & $\mathbf{1 5 . 3 0}$ & $\mathbf{0 . 1 3}$ & $\mathbf{1 1 7}$ & $\mathbf{1 8 4 . 4 7}$ \\
\hline
\end{tabular}

As shown in Table 4, the MILP model obtains the optimal result for all instances of the set $\mathrm{C} 1$, where its average CPU time is 20.76 seconds overall. Hence, its RPD values are zero for all the instances. The CP model also finds the optimal result for almost all (89 out of 90 ) instances of the set $\mathrm{C} 1$, and its average ARPD value is $0.02 \%$ overall. Also, the average CPU time of the CP model is 96.49 seconds overall. Even though both models perform well for these instances, it can be said that the MILP model slightly outperforms the CP model in terms of CPU time.

As seen in Table 5, the MILP model finds the optimal result for all instances of the set $\mathrm{C} 2$, and its RPD values are zero for all the instances, where its average CPU time is 16.24 seconds overall. On the other hand, the CP model finds the optimal result for only 
Table 3. The results of the MILP and CP models for the instance set R2

\begin{tabular}{|l|c|c|c|c|c|c|}
\hline \multirow{2}{*}{$\begin{array}{l}\text { Instance } \\
\text { Subset }\end{array}$} & \multicolumn{3}{|c|}{ MILP } & \multicolumn{3}{c|}{ CP } \\
\cline { 2 - 7 } & ARPD & \# of Opt. & Avg. CPU & ARPD & \# of Opt. & Avg. CPU \\
\hline R201 1-10 & 0.00 & 10 & 0.58 & 0.00 & 10 & 32.06 \\
\hline R202 1-10 & 0.00 & 10 & 6.14 & 4.00 & 7 & 1381.97 \\
\hline R203 1-10 & 0.00 & 10 & 10.29 & 10.06 & 2 & 3223.88 \\
\hline R204 1-10 & 0.00 & 10 & 18.04 & 8.17 & 0 & 3600.07 \\
\hline R205 1-10 & 0.00 & 10 & 0.98 & 1.78 & 8 & 1808.55 \\
\hline R206 1-10 & 0.00 & 10 & 16.22 & 8.20 & 2 & 3236.29 \\
\hline R207 1-10 & 0.00 & 10 & 12.88 & 9.97 & 1 & 3335.70 \\
\hline R208 1-10 & 0.00 & 10 & 20.56 & 7.49 & 0 & 3600.06 \\
\hline R209 1-10 & 0.00 & 10 & 3.62 & 9.53 & 2 & 3195.89 \\
\hline R210 1-10 & 0.00 & 10 & 2.76 & 11.85 & 2 & 2984.33 \\
\hline R211 1-10 & 0.00 & 10 & 15.94 & 15.91 & 0 & 3600.10 \\
\hline Overall & $\mathbf{0 . 0 0}$ & $\mathbf{1 1 0}$ & $\mathbf{9 . 8 2}$ & $\mathbf{7 . 9 1}$ & $\mathbf{3 4}$ & $\mathbf{2 7 2 7 . 1 7}$ \\
\hline
\end{tabular}

66 out of 80 instances of the set $C 2$, and its average ARPD value is $1.28 \%$ overall. Also, the average CPU time of the $\mathrm{CP}$ model is 676.97 seconds overall, which is much higher than the average CPU time of the MILP model. Consequently, it can be said that the MILP model clearly outperforms the CP model for the instance set of $\mathrm{C} 2$ in terms of all performance measures.

Looking at the results of the $\mathrm{C} 1$ and $\mathrm{C} 2$ sets in Tables 4 and 5, it can be inferred that the MILP and CP solution times follow a similar pattern. While the solution time of both is

Table 4. The results of the MILP and CP models for the instance set C1

\begin{tabular}{|l|c|c|c|c|c|c|}
\hline \multirow{2}{*}{$\begin{array}{l}\text { Instance } \\
\text { Subset }\end{array}$} & \multicolumn{3}{|c|}{ MILP } & \multicolumn{3}{c|}{ CP } \\
\cline { 2 - 7 } ARPD & \# of Opt. & Avg. CPU & ARPD & \# of Opt. & Avg. CPU \\
\hline C101 1-10 & 0.00 & 10 & 0.68 & 0.00 & 10 & 7.90 \\
\hline C103 1-10 & 0.00 & 10 & 13.14 & 0.00 & 10 & 22.35 \\
\hline C104 1-10 & 0.00 & 10 & 27.09 & 0.00 & 10 & 310.08 \\
\hline C105 1-10 & 0.00 & 10 & 141.86 & 0.15 & 9 & 509.25 \\
\hline C106 1-10 & 0.00 & 10 & 0.52 & 0.00 & 10 & 0.69 \\
\hline C107 1-10 & 0.00 & 10 & 0.60 & 0.00 & 10 & 2.64 \\
\hline C108 1-10 & 0.00 & 10 & 0.56 & 0.00 & 10 & 0.93 \\
\hline C109 1-10 & 0.00 & 10 & 2.05 & 0.00 & 10 & 3.74 \\
\hline Overall & $\mathbf{0 . 0 0}$ & $\mathbf{9 0}$ & $\mathbf{2 0 . 7 6}$ & $\mathbf{0 . 0 2}$ & $\mathbf{8 9}$ & $\mathbf{9 6 . 4 9}$ \\
\hline
\end{tabular}

long for data sets C103-C104 and C203-204, it is quite short for some other instances such as $\mathrm{C} 107$ and $\mathrm{C} 201$. The fact that both models exhibit similar behavior for the same instances indicates the difficulty and ease of these instance sets. The imbalance between solution times can be caused by cropping the data produced in the literature. The division of the data with 100 customers into 10 customers may have caused the distance between the customers to be unbalanced in the divided data sets. The imbalance of the data within the sets can also cause variation in the solution times of the MILP and CP models. 
Table 5. The results of the MILP and CP models for the instance set C2

\begin{tabular}{|l|c|c|c|c|c|c|}
\hline \multirow{2}{*}{$\begin{array}{l}\text { Instance } \\
\text { Subset }\end{array}$} & \multicolumn{3}{|c|}{ MILP } & \multicolumn{3}{c|}{ CP } \\
\cline { 2 - 7 } & ARPD & \# of Opt. & Avg. CPU & ARPD & \# of Opt. & Avg. CPU \\
\hline C201 1-10 & 0.00 & 10 & 0.46 & 0.00 & 10 & 0.27 \\
\hline C202 1-10 & 0.00 & 10 & 1.81 & 0.51 & 9 & 374.53 \\
\hline C203 1-10 & 0.00 & 10 & 13.51 & 4.36 & 6 & 1641.69 \\
\hline C204 1-10 & 0.00 & 10 & 95.55 & 5.38 & 1 & 3272.04 \\
\hline C205 1-10 & 0.00 & 10 & 0.34 & 0.00 & 10 & 6.06 \\
\hline C206 1-10 & 0.00 & 10 & 1.32 & 0.00 & 10 & 17.98 \\
\hline C207 1-10 & 0.00 & 10 & 12.69 & 0.00 & 10 & 44.53 \\
\hline C208 1-10 & 0.00 & 10 & 4.22 & 0.00 & 10 & 58.63 \\
\hline Overall & $\mathbf{0 . 0 0}$ & $\mathbf{8 0}$ & $\mathbf{1 6 . 2 4}$ & $\mathbf{1 . 2 8}$ & $\mathbf{6 6}$ & $\mathbf{6 7 6 . 9 7}$ \\
\hline
\end{tabular}

As shown in Table 6, the MILP model obtains the optimal result for all instances of the set RC1, where its average CPU time is 10.66 seconds overall. Hence, its RPD values are zero for all the instances. The $\mathrm{CP}$ model also finds the optimal result for all instances of the set RC1, and its RPD values are zero for all of them. The average CPU time of the CP model is 39.20 seconds overall. Even though both models provide similar good performance for these instances, it can be said that the MILP model slightly outperforms the CP model in terms of CPU time.

As seen in Table 7, again, the MILP model finds the optimal result for all instances of the set $\mathrm{RC} 2$, and its RPD values are zero for all the instances, where its average CPU time is 10.79 seconds overall. On the other hand, the CP model finds the optimal result for only 42 out of 80 instances of the set RC2, and its average ARPD value is $3.49 \%$ overall. Also, the average CPU time of the CP model is 1857.14 seconds overall, which is significantly higher than those of the MILP model. Consequently, it can be said that the MILP model significantly outperforms the $\mathrm{CP}$ model for the instance set of $\mathrm{RC} 2$ in terms of all performance criteria.

Table 6. The results of the MILP and CP models for the instance set RC1

\begin{tabular}{|l|c|c|c|c|c|c|}
\hline \multirow{2}{*}{$\begin{array}{l}\text { Instance } \\
\text { Subset }\end{array}$} & \multicolumn{3}{|c|}{ MILP } & \multicolumn{3}{c|}{ CP } \\
\cline { 2 - 7 } RC101 1-10 & ARPD & \# of Opt. & Avg. CPU & ARPD & \# of Opt. & Avg. CPU \\
\hline RC102 1-10 & 0.00 & 10 & 6.09 & 0.00 & 10 & 5.93 \\
\hline RC103 1-10 & 0.00 & 10 & 9.62 & 0.00 & 10 & 14.87 \\
\hline RC104 1-10 & 0.00 & 10 & 11.20 & 0.00 & 10 & 43.53 \\
\hline RC105 1-10 & 0.00 & 10 & 6.85 & 0.00 & 10 & 10.46 \\
\hline RC106 1-10 & 0.00 & 10 & 6.85 & 0.00 & 10 & 11.13 \\
\hline RC107 1-10 & 0.00 & 10 & 9.92 & 0.00 & 10 & 25.34 \\
\hline RC108 1-10 & 0.00 & 10 & 18.23 & 0.00 & 10 & 80.46 \\
\hline Overall & $\mathbf{0 . 0 0}$ & $\mathbf{8 0}$ & $\mathbf{1 0 . 6 6}$ & $\mathbf{0 . 0 0}$ & $\mathbf{8 0}$ & $\mathbf{3 9 . 2 0}$ \\
\hline
\end{tabular}

Finally, the detailed analysis of the computational results indicates the superior performance of the MILP model over the CP model, as the MILP model is able to find the optimal result for all instances in short computational times. Even though there is not a noteworthy difference between the results of the models for the instance sets R1, $\mathrm{C} 1$, and $\mathrm{RC} 1$, there is a significant difference between the performance of the models for the sets R2, C2, and RC2. For the instance sets R2, C2, and RC2, the MILP model 
clearly outperforms the $\mathrm{CP}$ model in terms of all performance criteria. Hence, it can be said that the MILP model performs much better than the CP model for the instance sets of type 2 that have a long planning horizon.

Table 7. The results of the MILP and CP models for the instance set RC2

\begin{tabular}{|l|c|c|c|c|c|c|}
\hline \multirow{2}{*}{$\begin{array}{l}\text { Instance } \\
\text { Subset }\end{array}$} & \multicolumn{3}{|c|}{ MILP } & \multicolumn{3}{c|}{ CP } \\
\cline { 2 - 7 } & ARPD & \# of Opt. & Avg. CPU & ARPD & \# of Opt. & Avg. CPU \\
\hline RC201 1-10 & 0.00 & 10 & 0.80 & 0.00 & 10 & 23.19 \\
\hline RC202 1-10 & 0.00 & 10 & 5.54 & 4.68 & 6 & 1497.14 \\
\hline RC203 1-10 & 0.00 & 10 & 9.84 & 5.55 & 1 & 3294.38 \\
\hline RC204 1-10 & 0.00 & 10 & 26.18 & 3.16 & 0 & 3600.08 \\
\hline RC205 1-10 & 0.00 & 10 & 1.38 & 0.00 & 10 & 195.38 \\
\hline RC206 1-10 & 0.00 & 10 & 0.80 & 2.54 & 8 & 949.87 \\
\hline RC207 1-10 & 0.00 & 10 & 3.67 & 2.38 & 7 & 1697.06 \\
\hline RC208 1-10 & 0.00 & 10 & 38.07 & 9.64 & 0 & 3600.02 \\
\hline Overall & $\mathbf{0 . 0 0}$ & $\mathbf{8 0}$ & $\mathbf{1 0 . 7 9}$ & $\mathbf{3 . 4 9}$ & $\mathbf{4 2}$ & $\mathbf{1 8 5 7 . 1 4}$ \\
\hline
\end{tabular}

\section{Conclusion}

In this article, we have studied a milk dispatching problem for a distribution company, which has a single depot and uses capacitated non-identical vehicles to distribute the milk to distinct customers. Each customer has its own available time interval, and the distributors should respect those intervals to distribute the milk. Hence, we consider the problem as a capacitated vehicle routing problem with time windows (CVRPTW).

The contributions of this study can be highlighted as follows: Two different novel exact models, i.e., the MILP and CP models, have been proposed for the CVRPTW with nonidentical vehicles and customers with time windows to minimize the total traveled distance and the storage cost of undelivered milk based on the lateness of deliveries. The wellknown benchmark instances from the literature have been modified with respect to the specifications of the considered problem. Then, the solutions of the models have been verified and compared using the modified benchmark set. An extensive computational study has been conducted, and it has revealed that both models perform well for our problem. It should also be noted that the MILP model performs better than the CP model in terms of solution quality and CPU time for the instance sets that have a long planning horizon.

The managerial implications of this study can be summarized as follows. No revenue is aimed to be obtained by the dispatching process of milk to the primary schools and impoverished families with children. Thus, the only purpose is to optimize resource usage of the dispatching organization, which is the total fuel consumption of vehicles and the total lateness cost of the delayed milk deliveries. The outputs of the MILP and CP models provide information to the managers of the dispatching organizations to help them decide which vehicle will be visiting which node in which order. Also, the other decisions provided by the models are the starting time of service for customers as well as the amount of time the customers are served late. Therefore, the decisions obtained by both models will be giving answers to the research question that is stated as the minimization of the total fuel consumption of vehicles and the total lateness cost of the delayed milk deliveries. 
In terms of the limitations of this study, the proposed solution methodologies are the exact solution methodologies. Thus, they can only provide optimal solutions on small-sized instances. Another limitation is the performance of the $\mathrm{CP}$ model on the instance sets that have a long planning horizon. The performance of the $\mathrm{CP}$ model should be enhanced with other techniques such as the integration of lower bounds especially for those type of instances.

Since we have proposed exact solution methodologies, we have solved our mathematical models on small-sized instance sets. As a future study, we are planning to solve both models on large-sized instances. A real-life case study might be conducted within this problem framework. Also, the CP model is aimed to be improved due to its nondominance over the MILP model. In addition, a hybrid model that employs both MILP and CP models or a CP-based heuristic algorithm has been planned to be developed in order to improve our solutions. Moreover, heuristic approaches can be developed for the CVRPTW to solve larger instances.

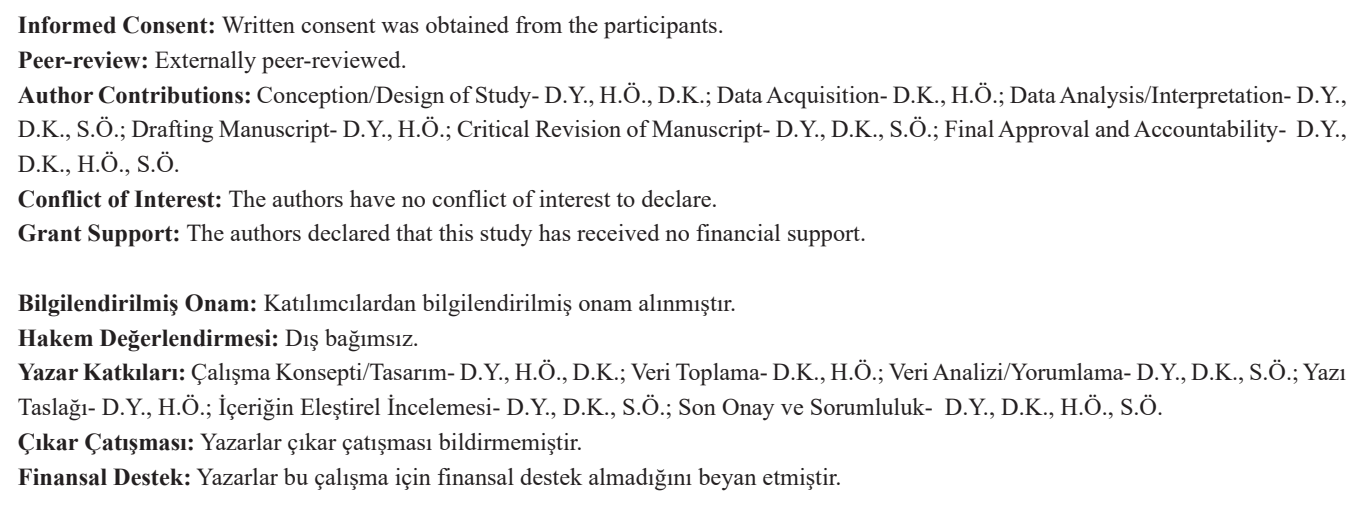

\section{References}

Amorim, P., Parragh, S. N., Sperandio, F., \& Almada-Lobo, B. (2014). A rich vehicle routing problem dealing with perishable food: A case study. TOP, 22(2), 489-508. https://doi.org/10.1007/s11750-012-0266-4

Bae, H., \& Moon, I. (2016). Multi-depot vehicle routing problem with time windows considering delivery and installation vehicles. Applied Mathematical Modelling, 40(13-14), 6536-6549. https://doi.org/10.1016/j. apm.2016.01.059

Booth, K. E. C., \& Beck, J. C. (2019). A Constraint Programming Approach to Electric Vehicle Routing with Time Windows. In Lecture Notes in Computer Science (including subseries Lecture Notes in Artificial Intelligence and Lecture Notes in Bioinformatics) (Vol. 11494 LNCS, pp. 129-145). Springer Verlag. https://doi.org/10.1007/978-3-030-19212-9_9

Braekers, K., Ramaekers, K., \& Van Nieuwenhuyse, I. (2016, September 1). The vehicle routing problem: State of the art classification and review. Computers and Industrial Engineering. Elsevier Ltd. https:// doi.org/10.1016/j.cie.2015.12.007

Butler, M., Herlihy, P., \& Keenan, P. B. (2005). Integrating information technology and operational research in the management of milk collection. Journal of Food Engineering, 70(3), 341-349. https://doi. org/10.1016/j.jfoodeng.2004.02.046

Caramia, M., \& Guerriero, F. (2010). A milk collection problem with incompatibility constraints. Interfaces, 40(2), 130-143. https://doi.org/10.1287/inte.1090.0475 
Claassen, G. D. H., \& Hendriks, T. H. B. (2007). An application of Special Ordered Sets to a periodic milk collection problem. European Journal of Operational Research, 180(2), 754-769. https://doi. org/10.1016/j.ejor.2006.03.042

De Backer, B., Furnon, V., Shaw, P., Kilby, P., \& Prosser, P. (2000). Solving vehicle routing problems using constraint programming and metaheuristics. Journal of Heuristics, 6(4), 501-523. https://doi. org/10.1023/A:1009621410177

El-Sherbeny, N. A. (2010). Vehicle routing with time windows: An overview of exact, heuristic and metaheuristic methods. Journal of King Saud University - Science, 22(3), 123-131. https://doi. org/10.1016/j.jksus.2010.03.002

Fatih Demiral, M. (2013a). Bulanık Doğrusal Programlama ile Süt Endüstrisinde Bir Uygulama - A Case Study at Dairy Industry with Fuzzy Linear Programming. Süleyman Demirel Üniversitesi İktisadi ve İdari Bilimler Fakültesi Dergisi, 18(2), 373-397.

Fatih Demiral, M. (2013b). Süt Endüstrisinde Optimizasyon İmkanları ve Bir Model Önerisi - Optimization Opportunities At Dairy Industry And A Model Proposal. Mehmet Akif Ersoy Üniversitesi Sosyal Bilimler Enstitüsü Dergisi, 5(8), 36-57. https://doi.org/10.20875/sb.18524

Gong, W., \& Fu, Z. (2010). ABC-ACO for perishable food vehicle routing problem with time windows. In Proceedings - 2010 International Conference on Computational and Information Sciences, ICCIS 2010 (pp. 1261-1264). https://doi.org/10.1109/ICCIS.2010.311

Guimarans, D., Herrero, R., Ramos, J. J., \& Padrón, S. (2011). Solving Vehicle Routing Problems Using Constraint Programming and Lagrangean Relaxation in a Metaheuristics Framework. International Journal of Information Systems and Supply Chain Management (IJISSCM), 4(2), 61-81.

Hà, M. H., Nguyen, T. D., Nguyen Duy, T., Pham, H. G., Do, T., \& Rousseau, L. M. (2020). A new constraint programming model and a linear programming-based adaptive large neighborhood search for the vehicle routing problem with synchronization constraints. Computers and Operations Research, 124, 105085. https://doi.org/10.1016/j.cor.2020.105085

Hentenryck, P. Van. (1999). The OPL Optimization Programming Language. MIT Press, Cambridge, MA, USA.

Hentenryck, P. Van. (2002). Constraint and Integer Programming in OPL. Informs Journal on Computing, 14(4), 345-372. https://doi.org/10.1287/ijoc.14.4.345.2826

Hojabri, H., Gendreau, M., Potvin, J.-Y., \& Rousseau, L.-M. (2018). Large neighborhood search with constraint programming for a vehicle routing problem with synchronization constraints. Computers and Operations Research, 92, 87-97. https://doi.org/10.1016/j.cor.2017.11.011

Johnson, D. S., \& Garey, R. M. (1979). A Guide to the Theory of NP-Completeness. Computers and Intractability.

Kumar, S. N., \& Panneerselvam, R. (2012). A Survey on the Vehicle Routing Problem and Its Variants. Intelligent Information Management, 04(03), 66-74. https://doi.org/10.4236/iim.2012.43010

Lahrichi, N., Crainic, T. G., Gendreau, M., Rei, W., \& Rousseau, L. M. (2015). Strategic analysis of the dairy transportation problem. Journal of the Operational Research Society, 66(1), 44-56. https://doi. org/10.1057/jors.2013.147

Li, J. qing, Han, Y. qi, Duan, P. yong, Han, Y. yan, Niu, B., Li, C. dong, . . Liu, Y. ping. (2020). Meta-heuristic algorithm for solving vehicle routing problems with time windows and synchronized visit constraints in prefabricated systems. Journal of Cleaner Production, 250, 119464. https://doi.org/10.1016/j.jclepro.2019.119464

Masson, R., Lahrichi, N., \& Rousseau, L. M. (2016). A two-stage solution method for the annual dairy transportation problem. European Journal of Operational Research, 251(1), 36-43. https://doi. org/10.1016/j.ejor.2015.10.058

Nalepa, J., \& Blocho, M. (2016). Adaptive memetic algorithm for minimizing distance in the vehicle routing problem with time windows. Soft Computing, 20(6), 2309-2327. https://doi.org/10.1007/s00500-015-1642-4

Öztop, H., Kizilay, D., \& Çil, Z. A. (2020). Mathematical models for the periodic vehicle routing problem with time windows and time spread constraints. International Journal of Optimization and Control: Theories and Applications, 11(1), 10-23. https://doi.org/10.11121/IJOCTA.01.2021.00899 
Paredes-Belmar, G., Lüer-Villagra, A., Marianov, V., Cortés, C. E., \& Bronfman, A. (2017). The milk collection problem with blending and collection points. Computers and Electronics in Agriculture, 134, 109-123. https://doi.org/10.1016/j.compag.2017.01.015

Paredes-Belmar, G., Marianov, V., Bronfman, A., Obreque, C., \& Lüer-Villagra, A. (2016). A milk collection problem with blending. Transportation Research Part E: Logistics and Transportation Review, 94, 26-43. https://doi.org/10.1016/j.tre.2016.07.006

Paredes-Belmar, G., Montero, E., \& Leonardini, O. (2021). A milk transportation problem with milk collection centers and vehicle routing. ISA Transactions. https://doi.org/10.1016/j.isatra.2021.04.020

Privé, J., Renaud, J., Boctor, F., \& Laporte, G. (2006). Solving a vehicle-routing problem arising in soft-drink distribution. Journal of the Operational Research Society, 57(9), 1045-1052. https://doi.org/10.1057/ palgrave.jors. 2602087

Rossi, F., Van Beek, P., \& Walsh, T. (2006). Handbook of Constraint Programming (Foundations of Artificial Intelligence). USA: Elsevier Science Inc.

Sethanan, K., \& Pitakaso, R. (2016). Differential evolution algorithms for scheduling raw milk transportation. Computers and Electronics in Agriculture, 121, 245-259. https://doi.org/10.1016/j.compag.2015.12.021

Sitek, P., Wikarek, J., Rutczyńska-Wdowiak, K., Bocewicz, G., \& Banaszak, Z. (2021). Optimization of capacitated vehicle routing problem with alternative delivery, pick-up and time windows: A modified hybrid approach. Neurocomputing, 423, 670-678. https://doi.org/10.1016/j.neucom.2020.02.126

Sitek, Pawel, \& Wikarek, J. (2019). Capacitated vehicle routing problem with pick-up and alternative delivery (CVRPPAD): model and implementation using hybrid approach. Annals of Operations Research, 273(12), 257-277. https://doi.org/10.1007/s10479-017-2722-x

Solomon, M. M. (1987). Algorithms for the Vehicle Routing and Scheduling Problems with Time Window Constraints. Operations Research, 35(2), 254-265. https://doi.org/10.1287/opre.35.2.254

Tarantilis, C. D., \& Kiranoudis, C. T. (2001). A meta-heuristic algorithm for the efficient distribution of perishable foods. Journal of Food Engineering, 50(1), 1-9. https://doi.org/10.1016/S0260-8774(00)00187-4

Tebaldi, L., Murino, T., \& Bottani, E. (2020). An adapted version of the water wave optimization algorithm for the capacitated vehicle routing problem with time windows with application to a real case using probe data. Sustainability (Switzerland), 12(9), 3666. https://doi.org/10.3390/su12093666 
